\title{
Latitudinal composition and spatial distribution of spiders (Aranei) in the vicinity of detached woodland (the Ary-Mas area, Taimyr)
}

\section{Широтный состав и пространственное распределение пауков (Aranei) в окрестностях островного месного массива (урочище Ары-Мас, Таймыр)}

\author{
Olga A. Khruleva ${ }^{1}$, Daniil V. Osipov ${ }^{2}$ \\ О.А. Хрулёва ${ }^{1}$, A.B. Осипов ${ }^{2}$
}

\footnotetext{
${ }^{1}$ Severtsov Institute of Ecology and Evolution, Russian Academy of Sciences, Leninsky prospekt 33, Moscow 119071, Russia. E-mail: oakhruleva@mail.ru

${ }^{2}$ Entomology Department, Moscow Zoo, Bolshaya Gruzinskaya 1, Moscow 123242, Russia. E-mail: spiders2000@yandex.ru

${ }^{1}$ Институт проблем экологии и эволюции имени А.Н. Северцова РАН, Ленинский просп., 33, Москва 119071, Россия.

${ }^{2}$ Отдел энтомологии Московского зоопарка, Большая Грузинская ул., 1, Москва 123242, Россия.
}

KEY WORDS: Russian Subarctic, Taimyr Peninsula, southern tundra, larch light forest, fauna, chorology, biotopic and stratified distribution, new records.

КЛЮЧЕВЫЕ СЛОВА: Российская Субарктика, Таймырский п-ов, южные тундры, лиственничное редколесье, фауна, хорология, биотопическое и ярусное распределение, новые отметки.

ABSTRACT. One of the northernmost places of larch forest growth in the southern tundra subzone is in the Ary-Mas area $\left(72.5^{\circ} \mathrm{N}\right)$. In this area, 54 species of spiders from nine families were collected; Agyneta amersaxatilis Saaristo et Koponen, 1998, Pardosa algens (Kulczyński, 1908), Semljicola beringianus (Eskov, 1989) and S. lapponicus (Holm, 1939) were first recorded on Taimyr. For the first three species, AryMas is the extreme known western point of its distribution, for S. lapponicus, it is the extreme eastern one. The peculiarities of the fauna composition have been revealed for this area, as well as the pattern spatial and stratified distribution of species and chorological groups. In the aboveground layer (sweeping on herbage and shrubs) 17 species and $23 \%$ of all specimens were collected, and in the ground-litter (epigeal) layer (collection by pitfall traps and by sifting moss and litter) - 45 species. Spider assemblages of the aboveground and ground-litter layer differed in taxonomic and latitudinal composition, as well as in the distribution pattern. Relatively rich spider assemblages in the herbage-undershrub layer (11 species, up to 50 specimens/100 sweeps) are represented only in the woodland. It was dominated by polyzonal hortobiontic Larinioides cornutus (Clerck, 1758) and Dictyna major Menge, 1869; outside the forest, their abundance was low. Spiders with arctic and hypoarctic distribution prevailed throughout the epigeal layer. Arctic spiders predominated in habitats where the zonal features of the climate are manifested in the most pure form (watershed slopes, high floodplain). Hypoarctic species play a significant role in the intrazonal habitats (sandy river bed, woodland). The high activity of arctic spe- cies distinguishes spider complexes of the Ary-Mas area from more western ones (regions of Europe and West Siberia). Obviously, in the studied territory, the detached forest plays an important role in the conservation of a number of rare species from other latitudinal fractions, as well as in the formation of relative rich hortobiontic spider assemblages under its canopy.

How to cite this article: Khruleva O.A., Osipov D.V. 2019. Latitudinal composition and spatial distribution of spiders (Aranei) in the vicinity of detached woodland (the Ary-Mas area, Taimyr) // Arthropoda Selecta. Vol.28. No.4. P.582-598. doi: 10.15298/arthsel. 28.4.13

РЕЗЮМЕ. Изучен состав фауны, а также пространственное распределение пауков в районе расположения на Таймыре одного из самых северных островных участков лиственницы Larix gmeleni (подзона южных тундр, урочище Ары-Мас, $72.5^{\circ}$ с.ш.). Здесь было собрано 54 вида из 9 семейств. Виды Agyneta amersaxatilis Saaristo et Koponen, 1998, Pardosa algens (Kulczyński, 1908), Semljicola beringianus (Eskov, 1989) и S. lapponicus (Holm, 1939) впервые отмечены на Таймыре. Для первых трёх видов Ары-Мас - крайняя западная известная точка их распространения, для $S$. lapponicus - крайняя восточная. В надземном ярусе (кошение по травостою и кустарникам) собрано 17 видов (23\% всех экз.), в напочвенном ярусе (почвенные ловушки, просеивание мха и подстилки) - 45 видов. Группировки пауков надземного и напочвенного яруса различались по таксономическому и широтному составу, а также чертами распределения на профи- 
ле ландшафта. Относительно богатые группировки пауков хортобия (11 видов, до 50 эКз./100 взм.) встречались только в лесном массиве. Их основу составили полизональные Larinioides cornutus (Clerck, 1758) и Dictyna major Menge, 1869, малочисленные в других биотопах. В напочвенном ярусе повсеместно доминировали арктические и гипоарктические виды пауков. Арктические виды формировали облик населения биотопов, где зональные черты климата были выражены наиболее ярко (склоны водораздела, высокая пойма), гипоарктические - в интразональных местообитаниях (лесной массив, песчаное русло реки). Высокая активность видов арктической фракции отличает изученный комплекс пауков от их зональных аналогов, представленных в южных тундрах Европы и Западной Сибири. Очевидно, что в изученном районе лес играет важную роль в сохранении ряда редких видов из других широтных фракций, а также в формировании относительно богатых группировок пауков в надземном ярусе.

\section{Introduction}

The araneofauna of the southern tundra subzone has been studied unevenly. The European and West Siberian regions are the most well studied [Eskov, 1986; Esyunin, 1999; Mazura, Esyunin, 2001; Tanasevitch, Koponen, 2007; Tanasevitch, Rybalov, 2010; Marusik, Koponen, 2015, etc.]. Based on these studies, spider fauna of the southern tundra was considered as a depleted boreal fauna, in which spiders with predominantly tundra distribution play a minor role [Eskov, 1986; Tanasevitch, Koponen, 2007]. Hypoarctic faunas of the Central Siberian Sector, as well as the Far Eastern [Marusik et al., 1992; Marusik, 1993], continue to be poorly studied. Some species were identified from the southern tundra of the Taimyr Peninsula [Eskov, 1985, 1986]; in addition, there is a list of species from its southwestern part [Osipov, 2003]. Meanwhile, the study of this territory is of particular interest, since the southern boundary of the tundra zone here has the greatest latitudinal position. In the tundra landscapes of eastern Taimyr are the most northern fragmented forests, formed by Larix gmelini. In one of these areas (the Ary-Mas area) spiders were collected in the forest and its vicinity. This article discusses the features of the latitudinal composition and spatial organization of the spider communities of this territory.

\section{Region and localities}

The Ary-Mas area is located in the southeast of the Taimyr Peninsula in the Khatanga River basin (see Map); its territory belongs to the Taimyr Nature Reserve. The relic detached forest located here is separated from the main part of a light forest from the south by a tundra strip 30-40 km wide. Detailed data on the natural conditions, flora and vegetation of this area are

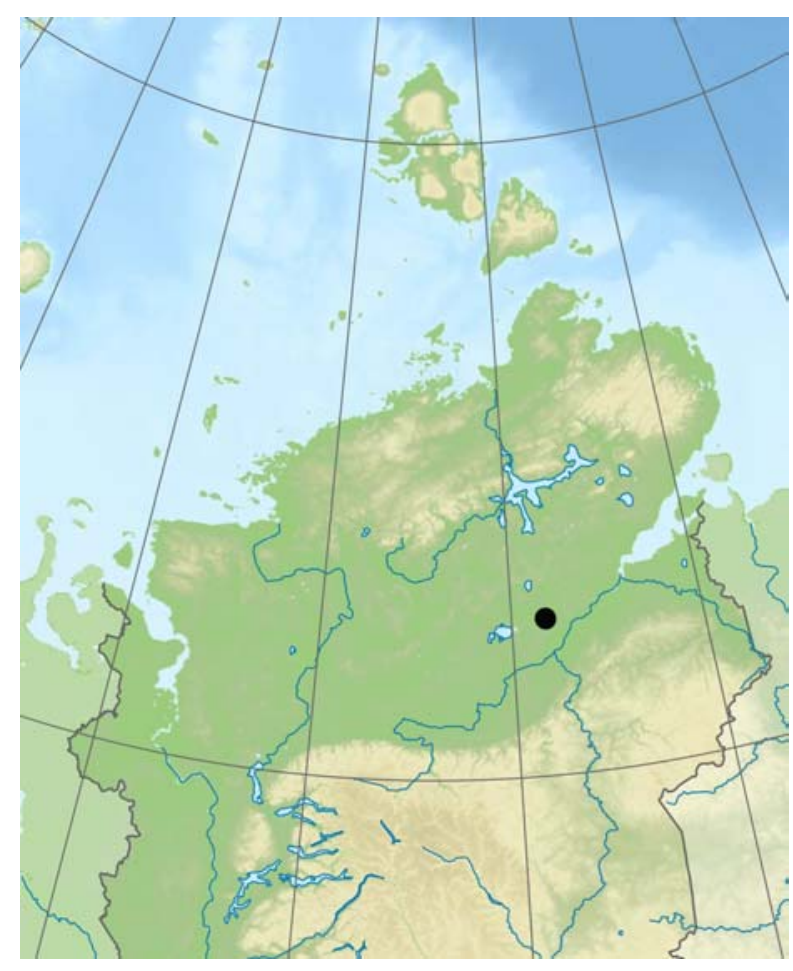

Map. Location of the Ary-Mas area on the map of Taimyr Peninsula.

Карта. Местоположение урочища Ары-Мас на карте Таймырского полуострова.

given in the monograph [Ary-Mas, 1978]. This area belongs to the subarctic climate zone, the average annual temperature is $-14{ }^{\circ} \mathrm{C}$, the average monthly temperature of the coldest month (January) is $-34^{\circ} \mathrm{C}$, and the summer months have a temperature of $4,12,9^{\circ} \mathrm{C}$, respectively. The duration of the frost-free period is about 100 days. The Ary-Mas area has a length of about $20 \mathrm{~km}$; its main part is bounded by the high terrace of the right bank of the Novaya River. Here is the light forest from Larix gmelini (crown density 0.30.5). Larch thickets alternate with wet depressions (background species Betula exilis, Ledum decumbens, Salix spp., Carex concolor, C. chordorrhiza, Drepanocladus spp., Sphagnum spp.). Closer to the watershed, the forest becomes more sparse (closure of 0.2), and then replaced by spotted shrub-sedge-moss tundra (Cassiope tetragona, Dryas punctata, Carex ensifolia ssp. àrctisibirica, Eriophorum vaginatum, Hylocomium splendens, Tomenthypnym nitens are predominated); thickets of bushes (Betula exilis, Salix lanata, S. pulchra) occupy depressions along the ravines and valleys of brooks. The river valley includes low, weakly overgrown sandy beaches, middle floodplain with willow bushes (Salix lanata, S. pulchra, S. glauca) and forbgrass meadows. The main surface of the high floodplain is occupied by wetlands, including polygonal bogs (with Carex concolor, Drepanocladus spp. in wet depressions and Betula exilis, Salix spp., Carex ensifolia, Hylocomium splendens, Aulacomnium turgidum on the dry plots). 

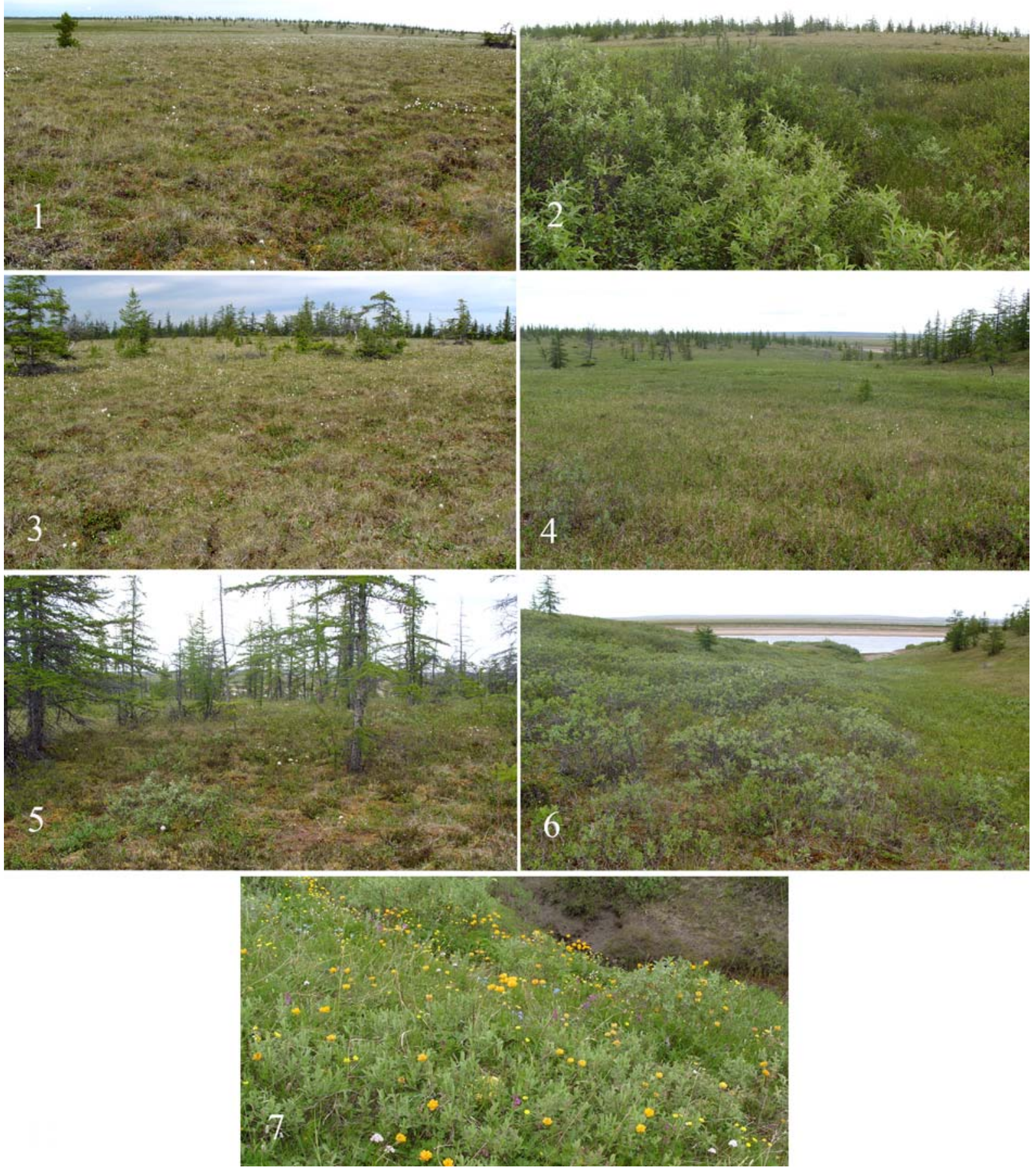

Figs. 1-7. Photographs of biotopes on the right bank of river. 1 - tundra with single larches on watershed; 2 - thickets of bushes in the creek valley; 3 - tundra with rare larches; 4 - wetland in the woodland; 5 - larch light forest; 6 - creek valley with willows in the woodland; 7 - coastal meadow.

Рис. 1-7. Фото биотопов на правом берегу реки: 1 - тундра с единичными лиственницами на водоразделе; 2 - кустарниковые заросли в долине ручья; 3 - тундра с разреженными лиственницами; 4 - сырая депрессия в лесном массиве; 5 лиственничное редколесье; 6 - долина ручья с ивняком в лесном массиве; 7 - прибрежный луг.

The studied biotopes (Figs 1-14) were located on a latitudinal transect about $5 \mathrm{~km}$ long: from the watershed of the right (southern) bank of the river $\left(72^{\circ} 26.767^{\prime} \mathrm{N}, 101^{\circ} 55.400^{\prime} \mathrm{E}\right)$ to a high floodplain occupying the left (northern) bank of the river $\left(72^{\circ} 27.848^{\prime} \mathrm{N}, 101^{\circ} 55.350^{\prime} \mathrm{E}\right)$. On the right bank, spiders were collected both in the forest and in its vicinity. On the left shore with single larches, different levels of the floodplain were investigated. The following biotopes were studied in this transect: 
Right bank of river.

R1. Spotted shrub-sedge-moss tundra with single larches on the watershed (Fig. 1).

R2. Dampish valley of the creek with thickets of bushes (Betula exilis, Salix spp.) (Fig. 2).

R3. Gentle slope of the river terrace with shrubsedge-moss cover and rare larches (Fig. 3).

R4. Wet depression with a shrub-sedge-moss-sphagnum cover surrounded by larch woodland (Fig. 4).

R5. Larch woodland with poorly developed shrub layer (Betula exilis, Salix spp.) and moss-shrub cover (Fig. 5).

R6. Creek valley, located within the larch woodland; willow bushes with sedge-moss cover in the lower tier (Fig. 6).

R7. Willow-horsetail-forb meadow on the northfacing river bank near riverbed (Fig. 7).

\section{Left bank of river.}

L8. Low sandy floodplain near riverbed with the single cereals (Fig. 8)

L9. Wet area of the middle floodplain with willow bushes (mainly by Salix lanata) and sedge-moss cover (Fig. 9).

L10. Dry sandy plots in the middle floodplain with grass-forb meadows and separate low willow bushes (Figs. 10-11)

L11. The edge of the high floodplain with horsetailherb meadow and some willow and larch bushes (Fig. 12).

L12. Dry edge of a high floodplain with spotty forb-grass-dryad cover (Fig. 13).

L13. Polygonal bog on a high floodplain with hummocky sedge-moss cover in depressions and forb-shrubsedge-moss cover on dry rollers (Fig. 14).

\section{Material and methods}

The material was collected by the first author on July 8-28, 2010 using various collecting techniques: pitfall traps (plastic, $200 \mathrm{~mL}$ cups filled one-third with water), sweep nets (no less than 4 series, 25 sweeps in each), litter and moss sifting, by hand. A total of about 950 spiders were collected, they were identified by the second author.

As before [Tanasevitch, Khruleva, 2017], we used the division of all species into four latitudinal fractions. The Arctic fraction includes 21 species with an optimal distribution in lowland landscapes that lie to the north of the forest boundary. These include arctic and metaarctic (according to: Gorodkov [1984]), as well as arcto-alpine and arcto-montane species (Table 1). For all of them, the term "arctic species" is used in the text. A small part of these species is most active in the northern part of the tundra zone, especially in the subzone of the arctic tundra (euarctic species), the rest uniformly inhabit the entire tundra zone or are more numerous in its southern part (hemiarctic species) [Chernov, Matveyeva, 2002]. Hypoarctic fraction includes 15 species with optimal distribution in landscapes of southern tundra subzone, forest tundra and subzone of northern taiga (hypoarcic distribution). Many of them are also found in mountain landscapes (hypoarto-montane and hypoarcto-boreo-montante type of distribution). Two "southern" fractions were also identified: the Boreal (6 species) and the Polyzonal (12 species).

To separate species into latitudinal fractions (especially for distinguishing hemiarctic species belonging to the Arctic fraction, and species from the Hypoarctic fraction), the following references were used: Eskov [1986], Marusik et al. [1992, 2001, 2013, 2016], Marusik [2005], Esyunin [1999, 2015], Tanasevitch \& Koponen [2007], Marusik \& Eskov [2009], Tanasevitch \& Rybalov [2010], Marusik \& Khruleva [2011], Marusik \& Koponen [2015], etc. Spiders Hybauchenidium aquilonare (L. Koch, 1879), Hilaira incondita (L. Koch, 1879), Alopecosa hirtipes (Kulczyński, 1907) have been attributed by some authors to hypoarctic species [Eskov, 1986; Esyunin, 2015]. We included all of them into the Arctic fraction, since they have the greatest activity in the tundra and sharply reduce it already in forest-tundra landscapes.

The spiders collected in the aboveground (sweeping in herbage-undershrub layer) and in the groundlitter (collections from pitfall traps and litter sifting) tiers were considered separately. Species were classified as dominant, if their share was $5 \%$ or more of the total number of the specimens collected in the biotope. Classification procedures were performed using the PAST program.

\section{Results}

\section{Chorological composition of the fauna and the} group of the most numerous species

In the study area, 54 species from 9 families were collected (Table 1), one of which (Aculepeira sp.) was not identified due to a lack of mature individuals. Agyneta amersaxatilis Saaristo et Koponen, 1998, Pardosa algens (Kulczyński, 1908), Semljicola beringianus (Eskov, 1989) and S. lapponicus (Holm, 1939) were first recorded on Taimyr. For the first three species, Ary-Mas is the extreme western known point of its distribution, for $S$. lapponicus, it is the extreme eastern one.

Spiders from the Arctic fraction were represented most diversely (about $40 \%$ of the fauna). Three of them - Diplocephalus barbiger (Roewer, 1955), Hilaira proletaria (L. Koch, 1879), Alopecosa mutabilis (Kulczyński, 1908) - belong to euarctic species, and all the rest (18) — to hemiarctic species. Species of Hypoarctic fractions make up about $28 \%$ of the fauna. About a third of all species belong to the "southern" fractions - Boreal and Polyzonal. The species of the last fraction are more diverse in the fauna (about $22 \%$ of the entire fauna); half of them are species that are regularly found in tundra landscapes: Larinioides cornutus 

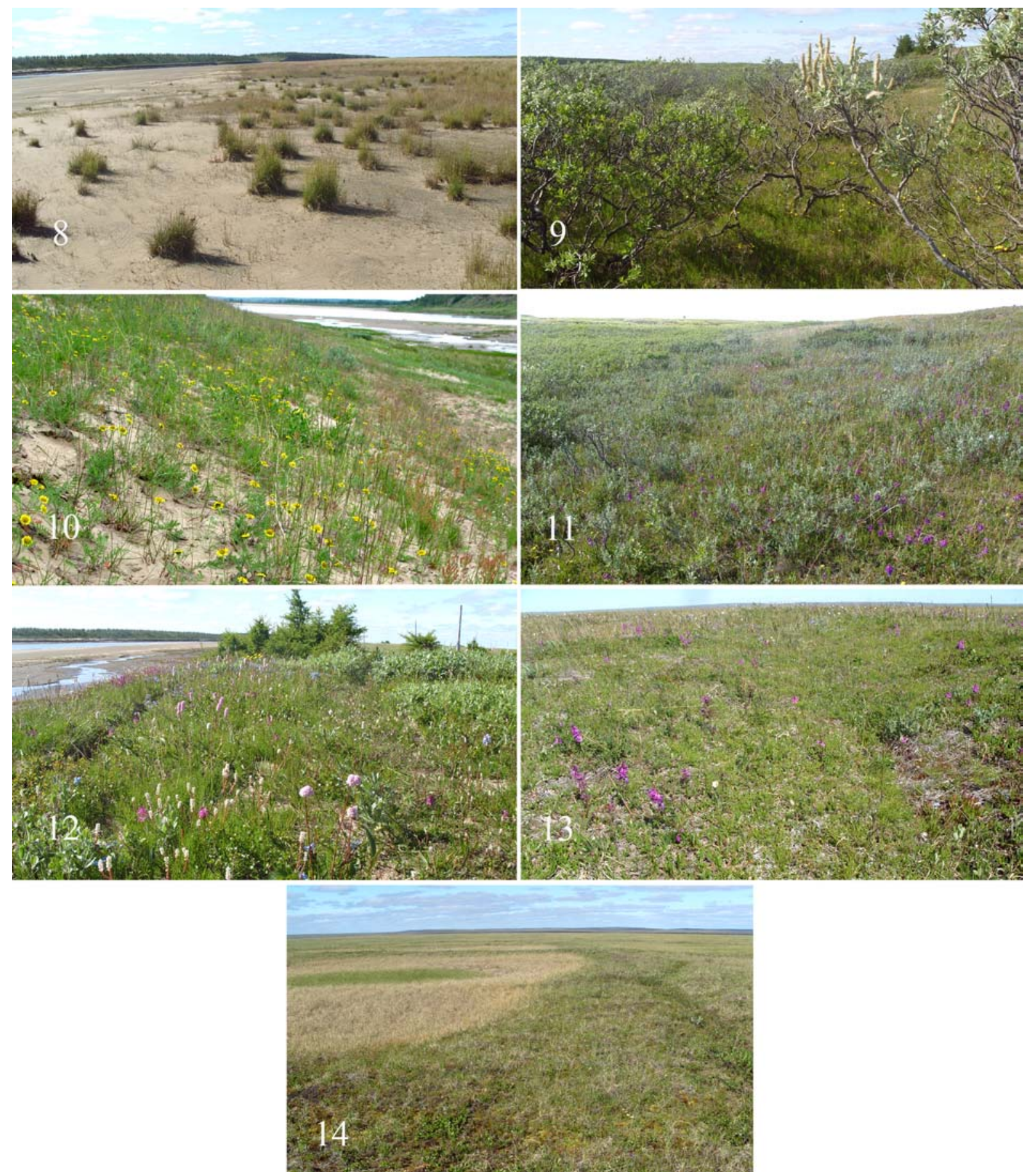

Figs. 8-14. Photographs of biotopes on the left bank of river. 8 - low sandy floodplain; 9 - wetland in the middle floodplain; $10-11$ - dry plots in the middle floodplain; 12 - mesophytic meadow on the edge of the high floodplain; 13 - herb-dryad cover on the edge of a high floodplain; 14 - polygonal bog on a high floodplain.

Рис. 8-14. Фото биотопов на левом берегу реки: 8 - низкая песчаная пойма; 9 - сырая депрессия на средней пойме; 10-11 - сухие участки средней поймы; 12 - мезофитный луг на бровке высокой пойме; 13 - дриадник на сухой бровке высокой поймы; 14 - полигональное болото на высокой пойме.

(Clerck, 1758), Dictyna major Menge, 1869, Hypselistes jacksoni (O. Pickard-Cambridge, 1903), Pelecopsis parallela (Wider, 1834), Walckenaeria korobeinikovi Esyunin et Efimik, 1996, Pachygnatha clercki Sundevall, 1823.
The composition of the spider fauna is characterized by a high proportion of species with the Siberian and Siberian-American distribution. Of the 26 species with Palearctic distribution, half belongs to the Siberian (another three arctic species are Fennoscandian- 
Table 1. Species composition, pattern of distribution and number of individuals of spiders collected by various methods in the Ary-Mas area.

Таблица 1. Видовой состав, типы ареалов и количество экземпляров пауков, собранных различными методами в урочище Ары-Мас.

\begin{tabular}{|c|c|c|c|c|c|}
\hline \multirow[b]{2}{*}{ Species } & \multirow{2}{*}{ 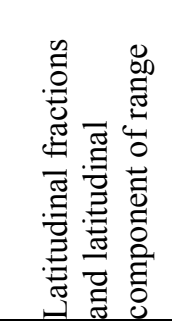 } & \multirow{2}{*}{ 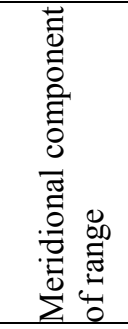 } & \multicolumn{3}{|c|}{ Collecting method } \\
\hline & & & $\begin{array}{l}\infty \\
. \\
0 \\
0 \\
0 \\
0 \\
0\end{array}$ & 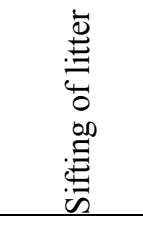 & 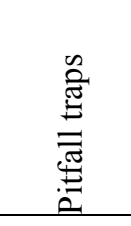 \\
\hline & 1 & 2 & 3 & 4 & 5 \\
\hline \multicolumn{6}{|c|}{ Fam. Araneidae } \\
\hline Aculepeira sp. & $\mathrm{P}$ & $\mathrm{Pl}$ & $4 \mathrm{jf}$ & - & - \\
\hline Araniella displicata (Hentz, 1847) & $\mathrm{B}$ & $\mathrm{Hl}$ & $1 f$ & - & - \\
\hline Larinioides cornutus (Clerck, 1758) & $\mathrm{P}$ & $\mathrm{Hl}$ & $56 \mathrm{mfj}$ & - & - \\
\hline \multicolumn{6}{|c|}{ Fam. Clubionidae } \\
\hline Clubiona latericia Kulczyński, 1926 & $\mathrm{~B}$ & S-WN & - & $1 \mathrm{f}, 1 \mathrm{jf}$ & - \\
\hline \multicolumn{6}{|c|}{ Fam. Dictynidae } \\
\hline Dictyna major Menge, 1869 & $\mathrm{P}$ & $\mathrm{Hl}$ & $95 \mathrm{mfj}$ & - & - \\
\hline Emblyna annulipes (Blackwall, 1846) & $\mathrm{P}$ & $\mathrm{Hl}$ & $1 \mathrm{f}$ & - & - \\
\hline \multicolumn{6}{|c|}{ Fam. Gnaphosidae } \\
\hline Gnaphosa orites Chamberlin, 1922 & $\mathrm{H}(\mathrm{h})$ & $\mathrm{Hl}$ & - & $1 \mathrm{~m}, 1 \mathrm{f}, 1 \mathrm{j}$ & $60 \mathrm{mfj}$ \\
\hline \multicolumn{6}{|c|}{ Fam. Linyphiidae } \\
\hline $\begin{array}{l}\text { Agyneta amersaxatilis Saaristo et } \\
\text { Koponen, } 1998\end{array}$ & A (a) & $\mathrm{S}-\mathrm{N}$ & $1 \mathrm{~m}$ & - & $3 \mathrm{~m}, 1 \mathrm{f}$ \\
\hline $\begin{array}{l}\text { A. cf. decora (O. Pickard-Cambridge, } \\
\text { 1871) }\end{array}$ & $\mathrm{P}$ & Pl-WN & - & $1 \mathrm{f}$ & - \\
\hline A. gulosa (L. Koch, 1869) & $\mathrm{B}$ & $\mathrm{Pl}$ & - & 1f & - \\
\hline A. nigripes (Simon, 1884) & A (a-a) & $\mathrm{Hl}$ & - & $4 f$ & - \\
\hline A. ripariensis Tanasevitch, 1984 & $\mathrm{H}(\mathrm{h}-\mathrm{m})$ & $\mathrm{S}$ & - & $1 \mathrm{~m}$ & - \\
\hline Bathyphantes humilis (L. Koch, 1879) & $\mathrm{H}(\mathrm{h})$ & $\mathrm{S}$ & $1 \mathrm{f}$ & $1 \mathrm{~m}, 6 \mathrm{f}$ & $3 \mathrm{~m}, 2 \mathrm{f}, 2 \mathrm{j}$ \\
\hline Connithorax barbatus (Eskov, 1988) & $\mathrm{H}(\mathrm{h})$ & $\mathrm{S}$ & - & $1 \mathrm{~m}, 1 \mathrm{f}$ & - \\
\hline Diplocephalus barbiger (Roewer, 1955) & A (a) & $\mathrm{S}-\mathrm{N}$ & - & $1 \mathrm{f}$ & $2 \mathrm{~m}, 2 \mathrm{f}$ \\
\hline $\begin{array}{l}\text { Erigone arctica sibirica Kulczyński, } \\
1908\end{array}$ & A (a) & $\mathrm{S}$ & - & 1f & $20 \mathrm{mfj}$ \\
\hline E. longipalpis (Sundevall, 1830) & $\mathrm{H}(\mathrm{h}-\mathrm{b}-\mathrm{m})$ & $\mathrm{Pl}$ & - & - & $19 \mathrm{mf}$ \\
\hline E. tirolensis L. Koch, 1872 & A (a-a) & $\mathrm{Hl}$ & $1 \mathrm{f}$ & $2 \mathrm{~m}$ & $29 \mathrm{mf}$ \\
\hline Gibothorax tchernovi Eskov, 1989 & A (a) & $\mathrm{S}$ & - & - & $1 \mathrm{~m}$ \\
\hline Gonatium rubens (Blackwall, 1833) & $\mathrm{P}$ & $\mathrm{Pl}$ & - & $1 \mathrm{~m}$ & 1f \\
\hline Halorates holmgreni (Thorell, 1871) & $\mathrm{A}(\mathrm{a}-\mathrm{m})$ & $\mathrm{Hl}$ & - & $1 \mathrm{~m}, 5 \mathrm{f}$ & $3 \mathrm{~m}, 7 \mathrm{f}$ \\
\hline Hilaira glacialis (Thorell, 1871) & $\mathrm{A}(\mathrm{a}-\mathrm{a})$ & $\mathrm{S}$ & - & $14 \mathrm{mf}$ & $1 \mathrm{f}$ \\
\hline H. herniosa (Thorell, 1875) & $\mathrm{B}$ & $\mathrm{Hl}$ & - & $3 \mathrm{f}, 4 \mathrm{j}$ & - \\
\hline H. incondita (L. Koch, 1879) & $\mathrm{A}(\mathrm{a})$ & $\mathrm{S}-\mathrm{N}$ & - & $2 \mathrm{f}$ & $2 \mathrm{~m}, 1 \mathrm{f}$ \\
\hline H. nivalis Holm, 1937 & $\mathrm{~A}(\mathrm{a})$ & ES-N & - & $1 \mathrm{~m}$ & - \\
\hline H. nubigena Hull, 1911 & $\mathrm{H}(\mathrm{h})$ & Pl-WN & - & - & $2 \mathrm{~m}, 1 \mathrm{f}$ \\
\hline
\end{tabular}


Table 1 (continued).

Таблица 1 (продолжение).

\begin{tabular}{|c|c|c|c|c|c|}
\hline & 1 & 2 & 3 & 4 & 5 \\
\hline \multicolumn{6}{|c|}{ Fam. Linyphiidae } \\
\hline Hilaira proletaria (L. Koch, 1879) & A (a) & S-WN & - & - & $1 \mathrm{~m}$ \\
\hline $\begin{array}{l}\text { Hybauchenidium aquilonare (L. Koch, } \\
\text { 1879) }\end{array}$ & A (a) & $\mathrm{S}-\mathrm{WN}$ & - & $9 \mathrm{mf}$ & - \\
\hline $\begin{array}{l}\text { Hypselistes jacksoni (O. Pickard- } \\
\text { Cambridge, 1903) }\end{array}$ & $\mathrm{P}$ & $\mathrm{Pl}$ & - & $1 \mathrm{~m}, 1 \mathrm{f}$ & - \\
\hline $\begin{array}{l}\text { Incestophantes laricetorum (Tanasevitch } \\
\text { et Eskov, 1987) }\end{array}$ & $\mathrm{B}$ & $\mathrm{S}$ & $1 \mathrm{f}$ & - & - \\
\hline Oreoneta leviceps (L. Koch, 1879) & A (a) & S-N & - & $10 \mathrm{f}$ & $3 \mathrm{~m}, 1 \mathrm{f}$ \\
\hline Pelecopsis parallela (Wider, 1834) & $\mathrm{P}$ & $\mathrm{Pl}$ & - & $1 \mathrm{~m}, 1 \mathrm{f}$ & $1 \mathrm{~m}, 1 \mathrm{f}$ \\
\hline Poeciloneta pallida Kulczyński, 1908 & $A(a-a)$ & $\mathrm{S}$ & $2 f$ & - & - \\
\hline Pseudocyba miracula Tanasevitch, 1984 & $\mathrm{~B}$ & $\mathrm{~S}$ & - & $5 f$ & $2 \mathrm{~m}$ \\
\hline Semljicola barbiger (L. Koch, 1879) & A (a-a) & FS & - & $2 \mathrm{~m}, 2 \mathrm{f}$ & - \\
\hline S. beringianus (Eskov, 1989) & $\mathrm{H}(\mathrm{h})$ & ES-WN & - & $2 \mathrm{f}, 4 \mathrm{j}$ & - \\
\hline S. lapponicus $($ Holm, 1939) & $\mathrm{H}(\mathrm{h})$ & FS-WN & - & 1f & - \\
\hline $\begin{array}{l}\text { Silometopoides sphagnicola Eskov et } \\
\text { Marusik, } 1992\end{array}$ & $\mathrm{H}(\mathrm{h}-\mathrm{b}-\mathrm{m})$ & $\mathrm{S}$ & - & $2 \mathrm{~m}$ & $2 \mathrm{~m}$ \\
\hline Tmeticus nigriceps (Kulczyński, 1916) & $\mathrm{H}(\mathrm{h}-\mathrm{m})$ & $\mathrm{S}$ & - & - & $1 \mathrm{~m}$ \\
\hline $\begin{array}{l}\text { Tubercithorax subarcticus (Tanasevitch, } \\
\text { 1984) }\end{array}$ & $\mathrm{H}(\mathrm{h})$ & $\mathrm{S}$ & - & $14 \mathrm{mf}$ & $2 \mathrm{f}$ \\
\hline Wabasso hilairoides Eskov, 1988 & A (a-a) & $\mathrm{S}$ & - & $1 \mathrm{~m}, 13 \mathrm{f}, 1 \mathrm{j}$ & - \\
\hline $\begin{array}{l}\text { Walckenaeria korobeinikovi Esyunin et } \\
\text { Efimik, } 1996\end{array}$ & $\mathrm{P}$ & EPl & - & $2 \mathrm{f}$ & - \\
\hline \multicolumn{6}{|c|}{ Fam. Lycosidae } \\
\hline Alopecosa hirtipes (Kulczyński, 1907) & A (a) & $\mathrm{S}-\mathrm{N}$ & - & $5 \mathrm{j}$ & $46 \mathrm{mfj}$ \\
\hline A. mutabilis (Kulczyński, 1908) & A (a) & S-WN & - & $1 \mathrm{j}$ & $5 f, 2 j$ \\
\hline Arctosa alpigena (Doleschall, 1852) & $\mathrm{H}(\mathrm{h})$ & $\mathrm{Hl}$ & - & $3 \mathrm{j}$ & $37 \mathrm{mfj}$ \\
\hline Pardosa algens (Kulczyński, 1908) & A (a) & S-N & - & - & $13 \mathrm{mfj}$ \\
\hline P. septentrionalis (Westring, 1861) & A (a) & FS & $4 \mathrm{j}$ & $8 \mathrm{j}$ & $106 \mathrm{mfj}$ \\
\hline P. tesquorum (Odenwall, 1901) & $\mathrm{H}(\mathrm{h}-\mathrm{b}-\mathrm{m})$ & S-WN & $1 \mathrm{j}$ & $1 \mathrm{f}, 4 \mathrm{j}$ & $151 \mathrm{mfj}$ \\
\hline \multicolumn{6}{|c|}{ Fam. Philodromidae } \\
\hline Thanatus arcticus Thorell, 1872 & $\mathrm{H}(\mathrm{h}-\mathrm{m})$ & FS-N & $1 \mathrm{f} 5 \mathrm{j}$ & $1 \mathrm{j}$ & $1 \mathrm{j}$ \\
\hline \multicolumn{6}{|c|}{ Fam. Tetragnathidae } \\
\hline Pachygnatha clercki Sundevall, 1823 & $\mathrm{P}$ & $\mathrm{Pl}$ & - & $1 \mathrm{f}, 1 \mathrm{j}$ & $1 \mathrm{f}, 1 \mathrm{j}$ \\
\hline Tetragnatha extensa (Linnaeus, 1758) & $\mathrm{P}$ & $\mathrm{Pl}$ & $1 \mathrm{~m}, 1 \mathrm{f}, 4 \mathrm{j}$ & - & - \\
\hline T. obtusa C.L. Koch, 1837 & $\mathrm{P}$ & $\mathrm{Pl}$ & $1 \mathrm{f}$ & - & - \\
\hline \multicolumn{6}{|c|}{ Fam. Thomisidae } \\
\hline Ozyptila arctica Kulczyński, 1908 & $\mathrm{H}(\mathrm{h}-\mathrm{m})$ & FS-N & $3 \mathrm{j}$ & $1 \mathrm{f}, 4 \mathrm{j}$ & $3 \mathrm{~m}, 1 \mathrm{f}, 1 \mathrm{j}$ \\
\hline Xysticus albidus Grese, 1909 & A (a) & FS & $2 f, 35 j$ & $1 \mathrm{~m}, 4 \mathrm{f}, 1 \mathrm{j}$ & $14 \mathrm{mfj}$ \\
\hline Total specimens & & & 221 & 164 & 558 \\
\hline Total species & & & 17 & 38 & 30 \\
\hline
\end{tabular}


Table 1 (continued). Таблица 1 (продолжение).

Gender and stage of development: $\mathrm{m}$ - male; $\mathrm{f}$ - female; $\mathrm{j}$ - juvenile. Latitudinal fractions: A — Arctic, $\mathrm{H}$ - Hypoarctic; B Boreal; P - Polyzonal. Latitudinal component of range (for Arctic and Hypoarctic fractions): a — arctic (including metaarctic range); a-a arcto-alpine; $\mathrm{a}-\mathrm{m}$ - arcto-montane; $\mathrm{h}$ - hypoarctic; $\mathrm{h}-\mathrm{b}-\mathrm{m}$ - hypoarcto-boreo-montane; $\mathrm{h}-\mathrm{m}$ - hypoarcto-montane. Meridional component of range: Hl — Holarctic; Pl — Palearctic; EPl — East Palearctic; FS — Fennoscandian-Siberian; S — Siberian; FS-N — Fennoscandian-Siberian-Nearctic; S-N — Siberian-Nearctic; S-WN - Siberian-West Nearctic; Pl-WN — Palearctic-West Nearctic.

Пол и стадия развития: $\mathrm{m}$ - самец; $\mathrm{f}$ - самка; $\mathrm{j}$ - ювенильный экземпляр. Широтные фракции: А — арктическая, $\mathrm{H}-$ гипоарктическая; В - бореальная; Р - полизональная. Широтная составляющая ареала (для арктической и гипоарктической фракций): a — арктический (включая метаарктический); a-a — аркто-альпийский; $\mathrm{a}-\mathrm{m}$ - аркто-монтанный; $\mathrm{h}$ - гипоарктический; h-b-m — гипоаркто-борео-монтанный; h-m — гипоаркто-монтанный. Меридиональная составляющая ареала: Нl — голарктический; $\mathrm{Pl}$ - палеарктический; EPl - восточнопалеарктический; FS — фенноскандинавско-сибирский; S - сибирский; FS-N фенноскандинавско-сибирско-неарктический; S-N - сибирско-неарктический; S-WN - сибирско-западнонеарктический; Pl$\mathrm{WN}$ - палеарктическо-западнонеарктический.

Siberian). Of the 28 species found in both Eurasia and North America, slightly less than half (13) are species of the Siberian-Nearctic distribution. Siberian and Siberian-Nearctic elements make up about half of all species (48\%). They are especially numerous among the species of the Arctic and Hypoarctic fractions (Fig. 15), whereas all polyzonal species, in contrast, have wide Holarctic and Palearctic ranges.

Among the most numerous species, which accounted for more than $1 \%$ of the total number of the collected spiders, arctic species dominated (10 out of 19 species). All of them are represented by hemiarctic species, widespread in the tundra zone: Erigone arctica sibirica Kulczyński, 1908, E. tirolensis L. Koch, 1872, Halorates holmgreni (Thorell, 1871), Hilaira glacialis (Thorell, 1871), Oreoneta leviceps (L. Koch, 1879), Wabasso hilairoides Eskov, 1988, Alopecosa hirtipes, Pardosa algens, P. septentrionalis (Westring,
1861), Xysticus albidus Grese, 1909. Of the hypoarctic species, the most numerous were Gnaphosa orites Chamberlin, 1922, Bathyphantes humilis (L. Koch, 1879), Erigone longipalpis (Sundevall, 1830), Tubercithorax subarcticus (Tanasevitch, 1984), Arctosa alpigena (Doleschall, 1852), Pardosa tesquorum (Odenwall, 1901), Ozyptila arctica Kulczyński, 1908. All of them were noted in the southern tundra of various regions. From the "southern" fractions there were only two numerous species: hortobiontic Larinioides cornutus and Dictyna major.

\section{Distribution features in different layers}

The aboveground layer. In the herbage-undershrub layer, 17 species from 7 families and 221 individuals ( $23 \%$ of all the taken spiders) were collected by sweeping (Table 1). Of these, 7 species and almost three quarters of the total number of the collected specimens

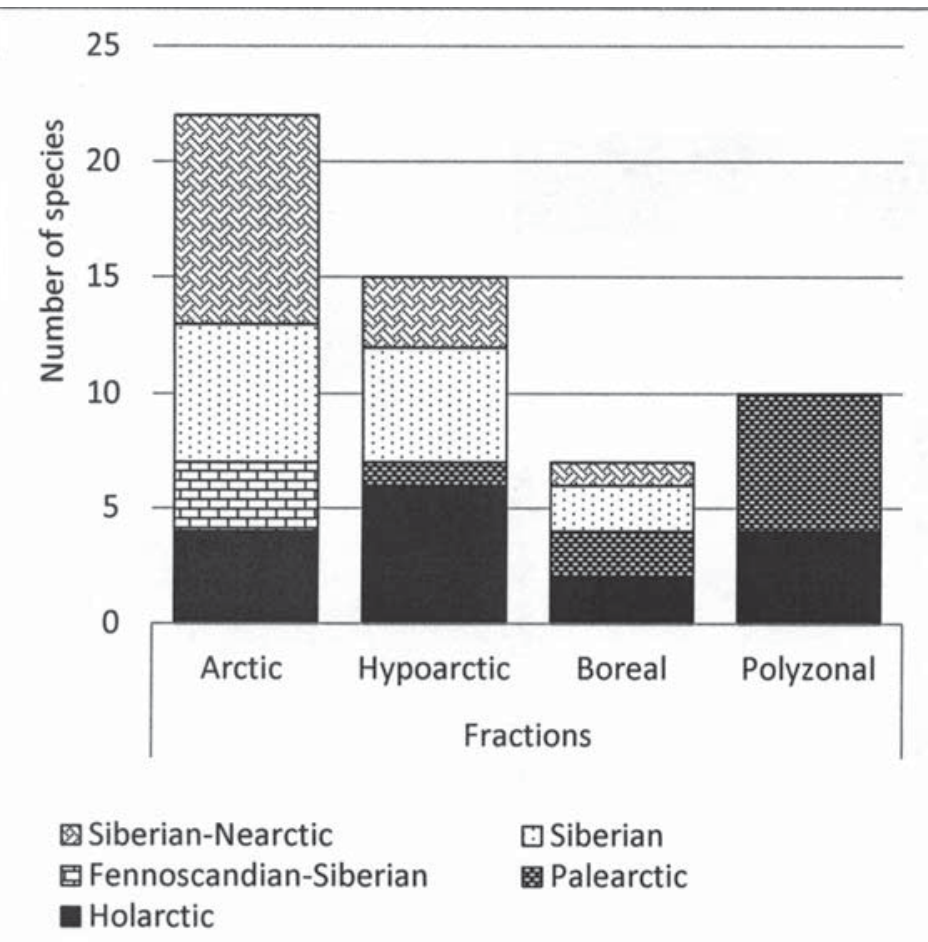

Fig. 15. Meridional composition of the ranges of spiders from the different latitudinal fractions.

Рис. 15. Долготный состав ареалов у пауков из различных широтных фракций. 
belong to specialized herbage-dwelling spiders; these are species from the family Araneidae and Dictynidae, as well as from the genus Tetragnatha (Tetragnathidae). Most of them have a polyzonal distribution, including the most abundant ones, Larinioides cornutus and Dictyna major. The rest of the spiders are mainly represented by arctic and hypoarctic species common to both layers. Most numerous among them are the Thomisidae species (about 18\% of all individuals in sweeps), especially the arctic Xysticus albidus. Linyphiidae, as well as Lycosidae (juvenile specimens of Pardosa spp.) have a low abundance in this layer.

Most specimens (more than $87 \%$ of all individuals in sweeps) were collected on the right bank of the river (Table 2). Here the largest number of species is noted 14, whereas on the left bank - only 7 . The greatest species richness and catchability (11 species, up to 50 specimens/100 sweeps) were recorded in the larch forest and the wetland located within the woodland. Polyzonal Larinioides cornutus and Dictyna major, prevailed in the sweeps $(34 \%$ and $51 \%$ of the collected individuals, respectively). Some other herbage-dwelling spiders (Aculepeira sp., Araniella displicata (Hentz, 1847)), as well as the species common to the groundlitter layer (Agyneta amersaxatilis, Bathyphantes humilis, Thanatus arcticus Thorell, 1872, Ozyptila arcti$c a$ ), were found in low amounts.

Outside the woodland, the total species richness and catchability of the most numerous species, Larinioides cornutus and Dictyna major, have declined sharply in the sweeps. Simultaneously, the abundance of Xysticus albidus increased significantly in tundra biotopes with rare larches. This species was represented predominantly by juvenile stage in the sweeps; also a few immature specimens of Pardosa septentrionalis were collected here (Tables 1,2).

Compared to the woodland and its surroundings (right bank of river), the average catchability of spiders in the sweeps on the left bank was significantly lower (Table 2). Spiders were absent in almost one-third of them, and in most others their numbers were extremely low. The only exception was the willow-forb-grass meadow (Fig. 11), where eight specimens of Dictyna major were collected once. Xysticus albidus also practically did not occur in the herbage-undershrub layer, although in the surface layer it was even more numerous than on the right bank (Tables 2, 3).

The ground-litter (epigeal) layer. In this layer, 45 species from 7 families were found $(30$ species - in the pitfall traps, 38 - in the litter sifting, 23 species were collected using both methods). Taxa that form the basis of the spider population in the herbage-undershrub layer (Araneidae, Dictynidae) were absent here. Lycosidae were the most numerous group in the pitfall traps (64\% of all collected samples), and Linyphiidae in the litter (about $75 \%$ of all collected samples). In contrast to the aboveground layer, where polyzonal species prevailed, the basis of the spider population in the epigeal layer formed the spiders from Arctic and
Hypoarctic fractions (Fig. 16). The most common (noted on both banks of the river) were species from the Arctic fraction, less often from Hypoarctic. The first were represented by Halorates holmgreni, Alopecosa hirtipes, Pardosa algens, P. septentrionalis, Xysticus albidus in pitfall traps and Hybauchenidium aquilonare, Hilaira glacialis, Oreoneta leviceps, Wabasso hilairoides in litter. From the Hypoarctic fraction, they included Arctosa alpigena, Pardosa tesquorum (pitfall traps) and Bathyphantes humilis, Tubercithorax subarcticus (litter).

Twenty-nine species were collected on the right bank of the Novaya River. Eleven of them were recorded only on this territory, mainly in the woodland (Table 3). Only few species (Gnaphosa orites, Arctosa alpigena, Ozyptila arctica) dominated here in various biotopes, some others (Hilaira herniosa (Thorell, 1875), Semljicola beringianus) had a relatively high amount only locally. In total, 22 species were collected in the woodland (in separate biotopes, 10-14 species). The most numerous among them were the hypoarctic species; their largest share in the spider population (70\%) was in the larch forest. Arctic species were mainly noted here in some specimens (with the exception of Pardosa septentrionalis). They were represented most diversely in the wetland ( 8 out of 10 species collected in the woodland).

At some distance from the woodland (undershrubsedge-moss tundra with sparse or single larches), the number of hypoarctic species decreased markedly. The only exception was the Gnaphosa orites, which dominated here along with the arctic Alopecosa hirtipes, Pardosa septentrionalis and Xysticus albidus. In general, the share of arctic species in these biotopes was $67-70 \%$ of the spider population. An even greater prevalence of arctic species (about 93\% of all captured individuals) was observed on the meadow of the northfacing coastal slope; its base consisted of Pardosa algens, Agyneta amersaxatilis and Halorates holmgre$n i$, also collected in the floodplain of the left bank (Table 3).

Thirty-four species were collected in the floodplain on the left bank. Almost half of them (16) were noted only here. In this territory, the species of the Arctic fraction were represented in much greater diversity than on the right (southern) coast (19 and 12 species, respectively). These differences may partly depend on the features of the sandy floodplain, where species associated with open substrates lived, such as Erigone arctica sibirica and E. tirolensis. However, for some other species the possibility of the barrier role of a large river, which limits their distribution to the south, cannot be excluded. Only here all three euarctic species (Diplocephalus barbiger, Hilaira proletaria, Alopecosa mutabilis) were collected. Some hypoarctic species (Erigone longipalpis, Silometopoides sphagnicola Eskov et Marusik, 1992, Hilaira nubigena Hull, 1911, Semljicola lapponicus, Tmeticus nigriceps (Kulczyński, 1916) were also noted only on the left bank. 


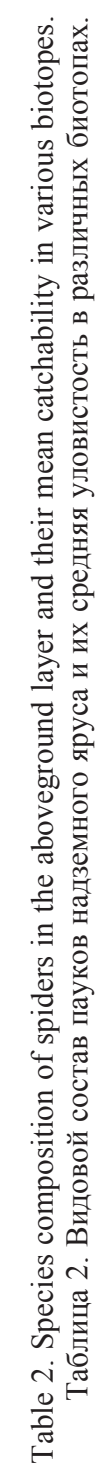

\begin{tabular}{|c|c|c|c|c|c|c|c|c|c|c|c|c|c|c|c|c|c|c|c|c|c|}
\hline \multirow{2}{*}{ 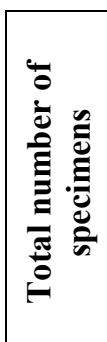 } & \multirow[t]{2}{*}{ 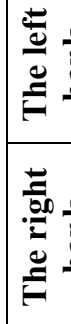 } & 1 & 1 & \multicolumn{2}{|c|}{$m:$} & $=1$ & $\sigma$ & - & \multicolumn{2}{|c|}{1} & 11 & $\begin{array}{rl}-1 & 1\end{array}$ & 1 & \multicolumn{2}{|c|}{$1-$} & $\begin{array}{lll}-1 & 1\end{array}$ & \multicolumn{2}{|c|}{$1-$} & $\stackrel{?}{-}$ & $r$ & $\begin{array}{l}8 \\
\stackrel{\circ}{2} \\
\text { N }\end{array}$ \\
\hline & & H & - & $\hat{n}$ & $\stackrel{\infty}{\sim}$ & - & $\sim$ & $\begin{array}{lll}1 & 1\end{array}$ & - & $-1-$ & -11 & - & $N$ & $\nabla$ & 1 & 0 & $m$ & $\begin{array}{l}0 \\
m\end{array}$ & $\stackrel{\Re}{ \pm}$ & \pm & 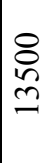 \\
\hline \multirow{11}{*}{$\begin{array}{l}\text { ڤ̆ } \\
\stackrel{0}{0} \\
\stackrel{0}{0}\end{array}$} & $\stackrel{m}{3}$ & I & 1 & ת & I & 1 & I & $\tilde{c}$ & I & I & I & 1 & 1 & 1 & 1 & 1 & 1 & กั & $\stackrel{0}{0}$ & $m$ & in \\
\hline & $\exists$ & I & 1 & I & $\ddot{0}$ & I & ? & I & I & I & I & I & 1 & 1 & 3 & 1 & 1 & 1 & $\stackrel{?}{-}$ & $m$ & 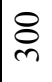 \\
\hline & $\stackrel{\varrho}{3}$ & I & 1 & 3 & $\stackrel{\circ}{\stackrel{\sim}{*}}$ & I & I & I & 1 & I & I & I & 1 & 1 & 1 & 1 & I & 1 & $\stackrel{m}{*}$ & $\sim$ & in \\
\hline & 9 & I & 1 & I & 1 & I & $n$ & I & I & I & l & I & 1 & 1 & 1 & 1 & 1 & 1 & $\stackrel{0}{-}$ & $\sim$ & $\underset{i}{\stackrel{i}{ }}$ \\
\hline & $\stackrel{\infty}{9}$ & I & 1 & $?$ & 3 & I & ? & $?$ & I & I & I & I & 1 & 1 & 1 & 1 & 1 & 1 & $\exists$ & $m$ & $\Varangle$ \\
\hline & $\hat{\simeq}$ & I & 1 & $\stackrel{\circ}{i}$ & $\stackrel{0}{-}$ & I & I & I & I & I & I & I & 1 & I & 1 & 1 & 1 & 1 & $\stackrel{0}{\dot{r}}$ & $\sim$ & 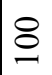 \\
\hline & $\begin{array}{l}* \\
\text { *n } \\
\stackrel{*}{*}\end{array}$ & $\ddot{0}$ & 1 & in & $\stackrel{\circ}{\stackrel{\circ}{ \pm}}$ & I & 1 & I & $\tilde{a}$ & $\begin{array}{l}n \\
b\end{array}$ & $?$ & $n$ & $\stackrel{\circ}{-}$ & I & 1 & $\ddot{n}$ & $\cong$ & $\because$ & $\stackrel{n}{n}$ & 으 & ¿্ণ \\
\hline & $\stackrel{*}{*} \underset{\simeq}{*}$ & I & $\stackrel{n}{0}$ & ?n? & $\stackrel{\circ}{\stackrel{0}{ \pm}}$ & I & 1 & 1 & 1 & 1 & I & I & 1 & 1 & 1 & $\ddot{0}$ & 1 & $\stackrel{m}{0}$ & $\stackrel{b}{\stackrel{i}{N}}$ & in & \&্ল \\
\hline & $\cong$ & $\tilde{n}$ & 1 & I & $\stackrel{0}{\dot{m}}$ & । & I & I & I & I & । & 1 & I & $\stackrel{0}{0}$ & 1 & 1 & 1 & $\begin{array}{l}0 \\
\ddot{n}\end{array}$ & $\vec{a}$ & $\nabla$ & ¿ \\
\hline & $\tilde{\simeq}$ & 1 & 1 & $\tilde{c}$ & $\tilde{0}$ & । & 0 & \begin{tabular}{l|l} 
\\
\end{tabular} & I & 1 & I & 1 & 1 & 1 & 1 & 1 & 1 & $\stackrel{\circ}{\circ}$ & $\ddot{0}$ & ナ & \&ి \\
\hline & $\bar{\simeq}$ & $\begin{array}{l}\stackrel{\bullet}{0} \\
0\end{array}$ & 1 & ? & 3 & $a$ & I & I & I & 1 & I & I & 1 & $\stackrel{0}{0}$ & I & I & 1 & $\ddot{n}$ & $\stackrel{\infty}{\sim}$ & 0 & $\begin{array}{l}\stackrel{n}{n} \\
m\end{array}$ \\
\hline
\end{tabular}

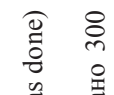

章

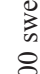

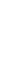




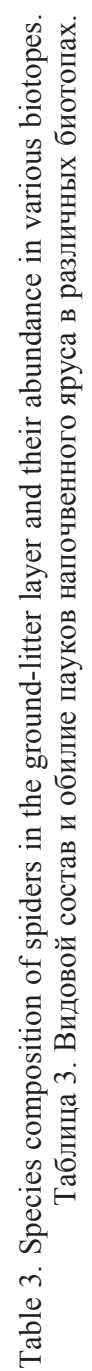

\begin{tabular}{|c|c|c|c|c|c|c|c|c|c|c|c|c|c|c|c|c|c|c|c|c|c|}
\hline 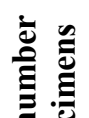 & 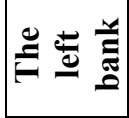 & $\because$ & - & 1 & $\sim$ & 1 & - & $m$ & 1 & $\stackrel{n}{-}$ & 1 & in & $\vec{\sim}$ & 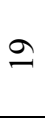 & $\bar{m}$ & - & 1 & 의 & $a$ & 1 & in \\
\hline हैं & 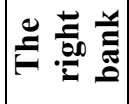 & \pm & - & 6 & $\sim$ & - & 1 & - & - & - & $\sim$ & 1 & 1 & 1 & 1 & 1 & $N$ & 0 & 6 & $r$ & \\
\hline \multirow{13}{*}{ } & $\stackrel{M}{3}$ & 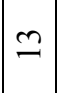 & 1 & 1 & 1 & 1 & 1 & 1 & 1 & 1 & 1 & 1 & 1 & 1 & 1 & 1 & 1 & 1 & $\stackrel{\infty}{1}$ & 1 & \\
\hline & $\exists$ & $\simeq$ & 1 & 1 & 1 & 1 & $F$ & $\stackrel{N}{T}$ & 1 & 1 & 1 & 1 & 1 & 1 & 1 & $\frac{1}{n}$ & 1 & 1 & $n$ & I & \\
\hline & $\exists$ & $=$ & 1 & 1 & 1 & 1 & 1 & $\vec{T}$ & 1 & $\stackrel{1}{n}$ & 1 & $\stackrel{1}{n}$ & $\stackrel{1}{6}$ & 1 & 1 & 1 & 1 & 1 & 1 & 1 & $\bar{T}$ \\
\hline & $\stackrel{9}{3}$ & $\stackrel{0}{0}$ & 1 & 1 & $\frac{1}{m}$ & 1 & 1 & 1 & 1 & $\frac{1}{n}$ & 1 & $\frac{1}{\infty}$ & $\underset{r}{i}$ & 1 & ○. & 1 & 1 & 1 & 1 & 1 & \\
\hline & 9 & $a$ & 1 & 1 & $\stackrel{t}{t}$ & 1 & 1 & 1 & 1 & $\stackrel{0}{n}$ & 1 & 1 & 1 & $\frac{1}{n}$ & 吕 & 1 & I & $\begin{array}{l}\stackrel{i}{\curvearrowright} \\
\end{array}$ & I & 1 & $\stackrel{1}{a}$ \\
\hline & $\stackrel{\infty}{\varrho}$ & $\infty$ & $\bar{T}$ & 1 & 1 & 1 & 1 & 1 & 1 & 1 & 1 & $F$ & $\stackrel{1}{6}$ & $\frac{1}{a}$ & 1 & 1 & 1 & 1 & 1 & 1 & $\bar{T}$ \\
\hline & $\underline{\simeq}$ & $r$ & 1 & 1 & $\stackrel{1}{\stackrel{1}{-}}$ & 1 & 1 & 1 & 1 & 1 & 1 & 1 & 1 & 1 & 1 & 1 & 1 & $\underset{\vec{f}}{\vec{i}}$ & 1 & 1 & \\
\hline & $\stackrel{*}{*}$ & 0 & 1 & $\underset{i}{\vec{f}}$ & 1 & 1 & 1 & 1 & 1 & 1 & 1 & 1 & 1 & 1 & 1 & 1 & 1 & 1 & 1 & $\hat{T}$ & \\
\hline & *ै* & in & $\vec{T}$ & 1 & 1 & 1 & 1 & 1 & $F$ & $F$ & 1 & 1 & 1 & 1 & 1 & 1 & $\begin{array}{l}\overrightarrow{1} \\
0 \\
0\end{array}$ & $\vec{T}$ & $\stackrel{m}{1}$ & 1 & \\
\hline & $\stackrel{*}{* *}$ & $\nabla$ & 1 & $\stackrel{\bar{a}}{\Xi}$ & 1 & 1 & 1 & 1 & 1 & 1 & 1 & 1 & 1 & 1 & 1 & 1 & 1 & 1 & $F$ & 1 & \\
\hline & $\mathscr{2}$ & $m$ & 1 & 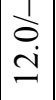 & 1 & $\vec{T}$ & 1 & $F$ & 1 & 1 & $\stackrel{N}{Y}$ & 1 & I & 1 & 1 & 1 & I & 1 & 1 & 1 & \\
\hline & $\cong$ & $\sim$ & 1 & $\begin{array}{r}\bar{n} \\
\dot{n}\end{array}$ & 1 & 1 & 1 & 1 & 1 & 1 & 1 & 1 & 1 & 1 & 1 & 1 & 1 & 1 & 1 & 1 & \\
\hline & $\bar{\simeq}$ & - & 1 & 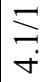 & 1 & 1 & 1 & 1 & 1 & 1 & 1 & 1 & 1 & 1 & 1 & 1 & 1 & 1 & $\stackrel{\mathrm{N}}{\mathrm{N}}$ & 1 & \\
\hline \multicolumn{2}{|r|}{ 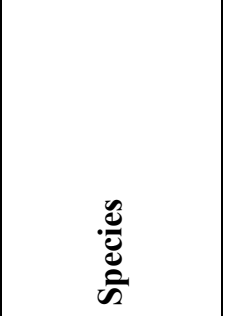 } & & 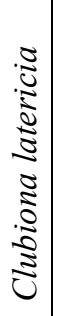 & 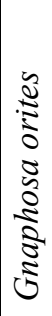 & 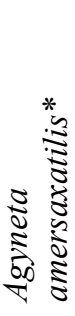 & 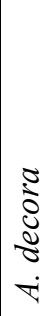 & $\mid \begin{array}{c}\tilde{D} \\
\tilde{\vdots} \\
\tilde{\Xi} \\
\tilde{s} \\
\dot{\nabla} \\
\dot{\nabla}\end{array}$ & 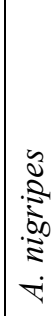 & 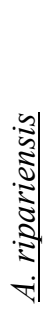 & 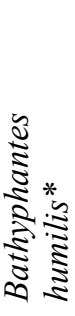 & 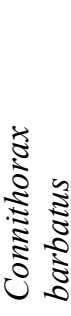 & 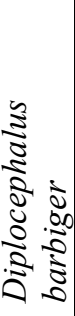 & 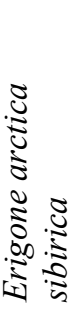 & 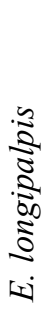 & 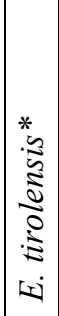 & 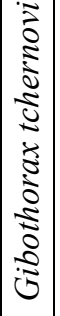 & 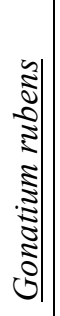 & 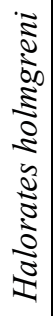 & 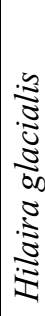 & 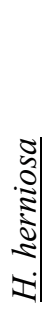 & 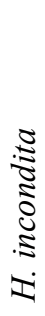 \\
\hline
\end{tabular}




\begin{tabular}{|c|c|c|c|c|c|c|c|c|c|c|c|c|c|c|c|c|c|c|c|c|c|c|c|}
\hline$\because$ & - & $m$ & - & 0 & 1 & $r$ & $\nabla$ & $r$ & - & 1 & - & $\nabla$ & - & $\Xi$ & $\simeq$ & 1 & $\stackrel{ \pm}{\sim}$ & $\infty$ & - & $\nabla$ & $\bar{m}$ & 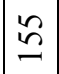 & I \\
\hline$\Xi$ & 1 & 1 & 1 & $m$ & $N$ & $r$ & 1 & 1 & $m$ & 0 & 1 & 1 & 1 & $\sim$ & $m$ & $\sim$ & $\hat{\imath}$ & 1 & ले & $a$ & $\infty$ & - & $N$ \\
\hline 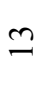 & $F$ & 1 & $\frac{1}{m}$ & $\stackrel{m}{1}$ & 1 & $\vec{T}$ & 1 & 1 & 1 & 1 & 1 & 1 & 1 & $\stackrel{\infty}{1}$ & $\vec{\nabla}$ & 1 & $\frac{N}{\sigma}$ & 1 & 1 & 1 & $\frac{1}{\lambda}$ & I & 1 \\
\hline$\simeq$ & 1 & 1 & 1 & 1 & 1 & 1 & 1 & 1 & 1 & 1 & 1 & 1 & 1 & $\frac{n}{n}$ & 1 & 1 & $\frac{1}{\partial}$ & $\begin{array}{l}\vec{\infty} \\
\dot{n}\end{array}$ & $\frac{1}{n}$ & I & $\stackrel{5}{n}$ & I & 1 \\
\hline$=$ & 1 & 1 & 1 & $\stackrel{N}{N}$ & 1 & $F$ & 1 & 1 & 1 & 1 & 1 & 立 & 1 & 1 & $\vec{T}$ & 1 & & I & 1 & & I & $\underset{\sigma}{a}$ & 1 \\
\hline 으 & 1 & 1 & 1 & $F$ & 1 & $\frac{1}{n}$ & $\stackrel{v}{T}$ & $\sqrt{n}$ & 1 & 1 & 1 & $\frac{1}{3}$ & $\frac{1}{m}$ & 1 & 1 & 1 & $\stackrel{8}{\frac{1}{0}}$ & 1 & I & $\frac{1}{m}$ & $\stackrel{\text { f }}{\mathrm{f}}$ & 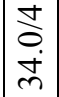 & 1 \\
\hline$a$ & 1 & $\begin{array}{l}1 \\
= \\
=\end{array}$ & 1 & 1 & 1 & \begin{tabular}{l}
$\mathrm{N}$ \\
\multirow{0}{*}{}
\end{tabular} & $\frac{1}{\stackrel{2}{0}}$ & $\stackrel{+}{T}$ & $\bar{T}$ & 1 & $F$ & $\stackrel{T}{T}$ & 1 & 1 & 1 & 1 & $\frac{1}{m}$ & 1 & 1 & 1 & $\frac{1}{m}$ & $\stackrel{1}{=}$ & \\
\hline
\end{tabular}

$\infty$

$\underset{1}{\frac{1}{2}} \frac{1}{n}$

\begin{tabular}{|c|c|c|c|c|c|c|c|c|c|c|c|c|c|c|c|c|c|c|c|c|c|c|}
\hline & & & & & 1 & 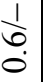 & 1 & 1 & 1 & 1 & 1 & 1 & 1 & 1 & I & 1 & $\begin{array}{l}1 \\
\\
0\end{array}$ & 1 & & $\overrightarrow{\hat{i}}$ & I & \\
\hline & & & & & $\stackrel{\Upsilon}{\uparrow}$ & 1 & 1 & I & 1 & 1 & 1 & 1 & 1 & 1 & $F$ & $F$ & $\begin{array}{l}\frac{1}{0} \\
0\end{array}$ & 1 & $\begin{array}{l}\vec{\infty} \\
\dot{m}\end{array}$ & $\begin{array}{l}\frac{1}{6} \\
0 \\
0\end{array}$ & $\stackrel{0}{1}$ & \\
\hline & & & & & 1 & 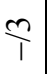 & 1 & 1 & $\stackrel{N}{N}$ & 1 & 1 & 1 & 1 & 1 & $\stackrel{N}{Y}$ & 1 & $\begin{array}{l}\frac{1}{6} \\
0 \\
0\end{array}$ & 1 & $\begin{array}{c}\vec{m} \\
i\end{array}$ & - & $\frac{1}{n}$ & \\
\hline & & & & 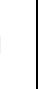 & I & $F$ & 1 & 1 & $F$ & $\stackrel{0}{T}$ & 1 & 1 & 1 & $\begin{array}{l}\frac{1}{0} \\
0 \\
0\end{array}$ & 1 & 1 & $\begin{array}{l}\vec{f} \\
i\end{array}$ & 1 & $\begin{array}{l}\frac{1}{2} \\
\infty \\
\infty\end{array}$ & 1 & $\underset{\forall}{\stackrel{f}{r}}$ & I \\
\hline & & & & | & I & 1 & 1 & 1 & 1 & 1 & 1 & 1 & 1 & 1 & 1 & 1 & 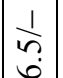 & 1 & 1 & 1 & $\begin{array}{l}0 \\
0 \\
n\end{array}$ & $T$ \\
\hline & & & & $\hat{\uparrow}$ & I & $\stackrel{N}{T}$ & 1 & I & 1 & 1 & 1 & 1 & 1 & 1 & 1 & 1 & $\begin{array}{l}1 \\
0 \\
0\end{array}$ & 1 & $\vec{T}$ & 1 & סִ & 1 \\
\hline & 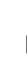 & & & | & 1 & 1 & 1 & I & 1 & 1 & 1 & 1 & 1 & $\bar{T}$ & 1 & $\bar{T}$ & $\begin{array}{l}\tilde{c} \\
\dot{i} \\
i\end{array}$ & 1 & 1 & I & $\begin{array}{l}5 \\
6 \\
i\end{array}$ & $\frac{1}{m}$ \\
\hline & 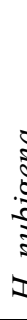 & & & & 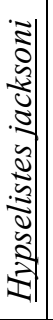 & 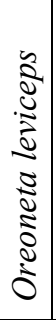 & 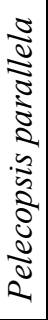 & 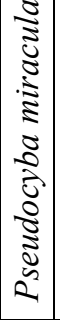 & 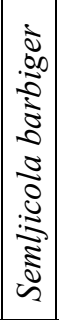 & 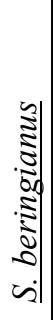 & 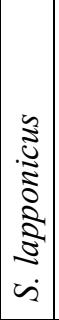 & 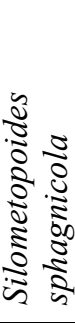 & 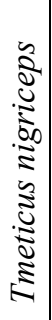 & 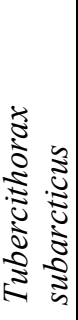 & 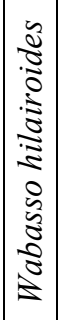 & 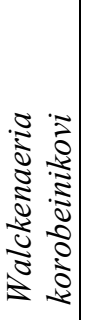 & 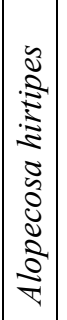 & 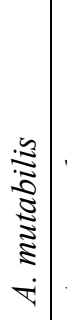 & 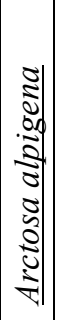 & 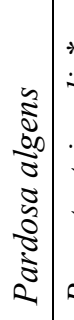 & 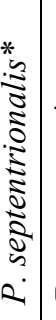 & 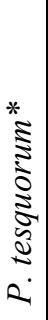 \\
\hline
\end{tabular}



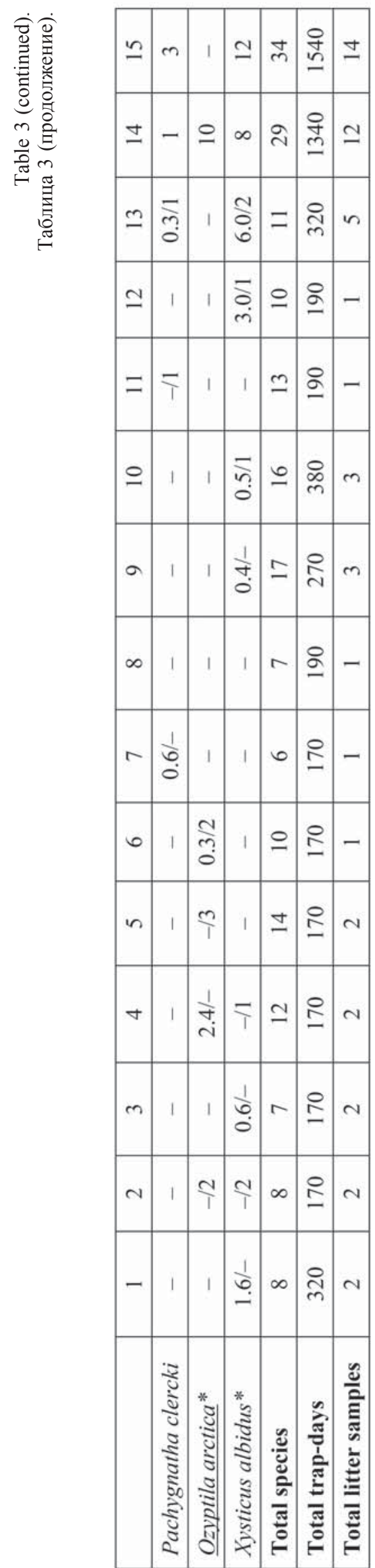

Of these, only E. longipalpis had a high abundance and formed the basis of the spider population ( $58 \%$ of all selected individuals) of the lower floodplain (Fig. 8), where only 7 species were collected.

On the middle floodplain, both biotopes with high humidity (in depressions) and dry areas were represented. In them (as well as on the mesophytic meadow at the edge of a high floodplain) the spider assemblages were much richer in species composition (13-17 species) and mainly consisted of common species (Table 3). Spiders of the Arctic and Hypoarctic fractions prevailed here. Arctic Halorates holmgreni, Erigone tirolensis and hypoarctic Bathyphantes humilis predominated in wet depression. In dry and sandy plots, the most common species was the hypoarcto-boreo-montane Pardosa tesquorum (69\% of all specimens collected). However, in the fauna of this biotope, more than half were arctic species (9 species out of 16), two of which, Erigone arctica sibirica and E. tirolensis, reached the high abundance (their share in the spider population was about $20 \%$ ). The same situation was on the mesophytic meadow: P. tesquorum was dominant ( $46 \%$ of the population), but the fauna of this biotope was formed mainly by arctic species (9 of 13).

The proportion of arctic species elsewhere in the high floodplain was $76-86 \%$ of the population. Only Tubercithorax subarcticus among the hypoarctic species was found in marked abundance. On the dry edge with the dryad cover, Xysticus albidus, Alopecosa hirtipes and A. mutabilis were predominated; the last species was found only here. The first two species, as well as Pardosa septentrionalis and the rare for this region Hilaira glacialis and Wabasso hilairoides, formed the basis of the population in the polygonal bog, which occupies the main part of the high floodplain. Only in this biotope, two more arctic species were found: $\mathrm{Hi}$ laira proletaria and H. nivalis Holm, 1937.

The features of the spatial organization of terrestrial spider assemblages are well illustrated by a dendrogram (Fig. 17). It shows that the most isolated position is occupied by spider populations of low levels in the floodplain of the left bank and coastal meadow on the right bank. The rest of the spider assemblages formed two groups. One cluster united spider populations from the woodland and thickets of bushes located on the right bank, and the other — from open biotopes on both banks of the river.

\section{Discussion}

\section{General features of the spider spread in the study area}

In the herbage-undershrub layer, relatively rich and numerous spider communities were represented only in the woodland. They differed sharply from the terrestrial spider population in taxonomic and zonal composition. Polyzonal herbage-dwelling species prevailed in the spider population, but typical terrestrial spiders, which were absent in sweeps in other biotopes, were 


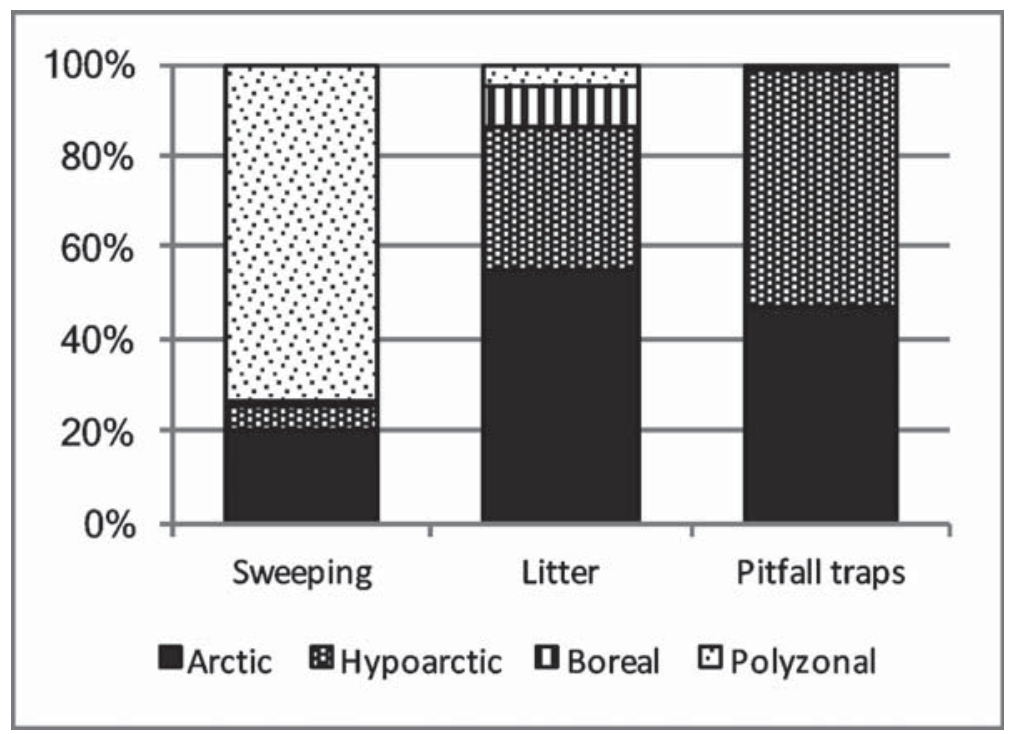

Fig. 16. The latitudinal composition of the spider samplings (from the total number of specimens) collected by various methods. Рис. 16. Широтный состав выборок пауков (от общего числа экземпляров), собранных различными методами.

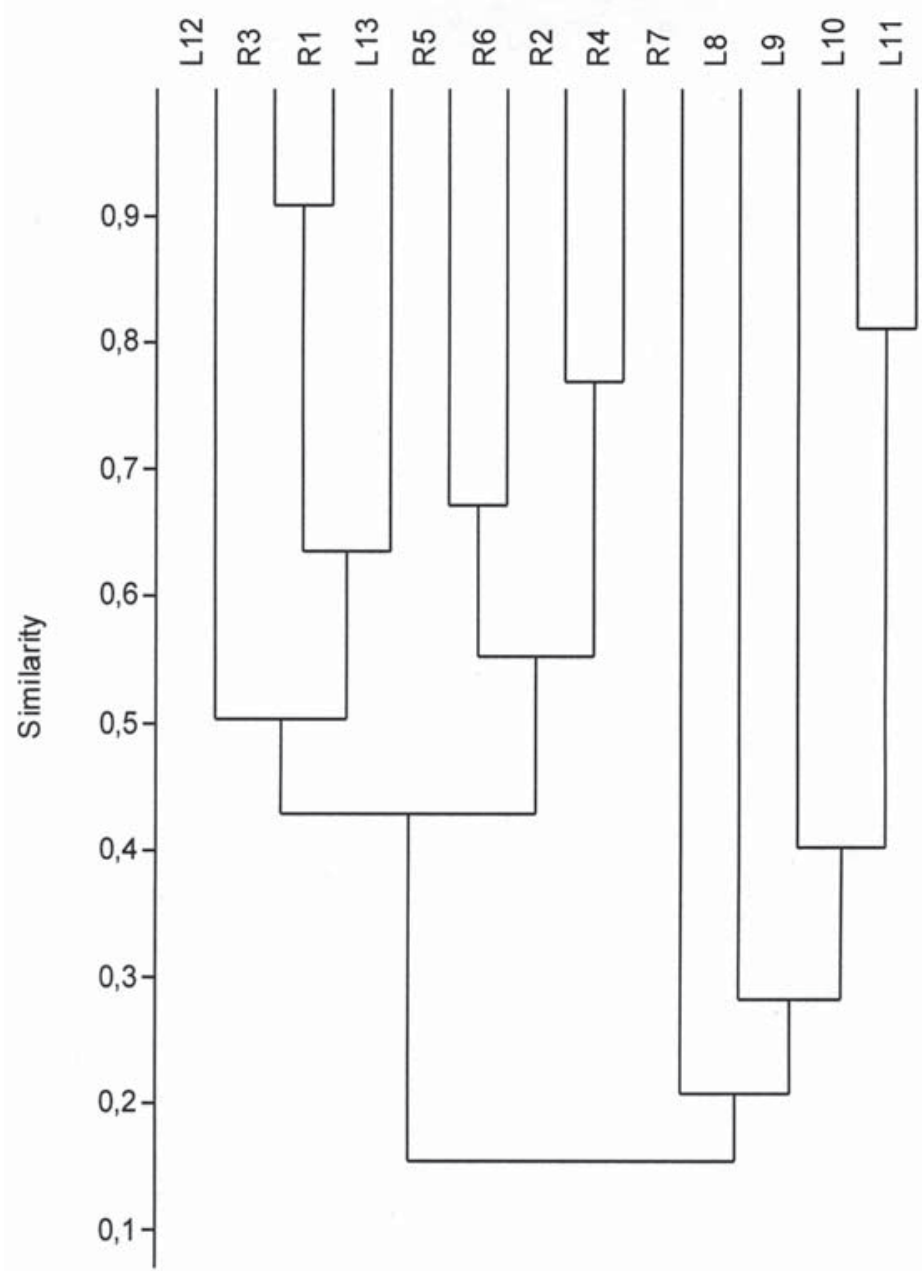

Fig. 17. Dendrogram of the similarity of terrestrial spider assemblages of various biotopes (PAST program, Horn index (paired group)).

Рис. 17. Дендрограмма сходства населения наземных пауков различных биотопов (PAST program, Horn index (paired group)). 
also found here. Therefore, we can assume that under the forest canopy there are favorable conditions for life in this layer for spiders with different environmental preferences. Another feature of the spider assemblages represented on the right bank near the forest was the high abundance of Xysticus albidus in the aboveground layer.

In contrast to the aboveground layer, all of the studied terrestrial spider assemblages had a well pronounced tundra character. They are based on species from Arctic and Hypoarctic fractions. Arctic Alopecosa hirtipes, Pardosa septentrionalis, Xysticus albi$d u s$ were especially widespread and inhabited the zonal and close to them biotopes on both banks of the river. The influence of the woodland on spiders of the epigeal layer was not so pronounced. It consisted in limiting several species of this territory, most of which were noted here in low amounts. The spider assemblages in the riverbed differed most sharply from the others. The dominant species here were spiders that prefer open substrates (Erigone spp., Pardosa tesquorum). It also collected the largest number of rare spiders for the area, including many arctic species.

Summing up the features of the distribution of spiders in the study area, one can be noted that the arctic species with rather wide ranges (inhabiting both different subzones of the tundra zone and high mountains) occupy leading positions in the landscape profile. They form the basis of the spider populations in habitats where the zonal features of the climate are manifested in the most pure form (watershed slopes, high floodplain). Hypoarctic species play a significant role only in those habitats, where climatic conditions are noticeably smoothed - in the riverbed and in the forest. In addition to this, few "southern" species also reach a marked abundance in the forest. These are mainly herbage-dwelling spiders, which determines here the formation of a clear stratified structure of spider assemblages.

Features of the studied araneofauna compared with those located elsewhere in the southern tundra

The species richness of the well-studied (two seasons) local fauna of the southern tundra of western Taimyr (ridge Nyapan, $70^{\circ} 05^{\prime} \mathrm{N}, 87^{\circ} 26^{\prime} \mathrm{E}$ ) is about 70 species of spiders [Osipov, 2003, with additions]. It is obvious that in a rather short period, the fauna of Ary Mas area was not fully studied. Nevertheless, it was possible to obtain interesting data on the composition and spatial distribution of spiders in the area.

Species that inhabit the aboveground layer in tundra landscapes are usually not studied specifically because of their small numbers. However, it is known that Araneidae, Dictynidae, and Tetragnathidae predominate among specialized chortobionts in the southern part of the tundra zone. Available data on these families from different tundra regions indicate significant variability in their composition (Table 4). They consist of spiders of "southern" faunal complexes (boreal and polyzonal), of which only Larinioides cornutus and Dictyna major have a clearly higher potential for colonization of the tundra [Tanasevitch, Koponen, 2007; Marusik et al., 2016; Tanasevitch, Nekhaeva, 2016; Tanasevitch, Khruleva, 2017]. Just these species form the basis of the spider population in the grass-undershrub layer in the Ary-Mas area.

The total diversity of hortobionic species in the Ary-Mas area is higher than in most other areas of the southern tundra. This is also evident when comparing with western Taimyr, where their species richness is noticeably lower (Table 4). On the contrary, the composition of terrestrial spiders [Osipov, 2003] in these areas of southern Taimyr is quite similar: more than 30 species are common to both faunas, and their basis is made up of species from the Arctic and Hypoarctic fractions. The spatial distribution of arctic species in these areas also has much in common: some species are widely distributed, but most of them occupy azonal habitats - wetlands and habitats with a large number of bare soils (pioneer communities: sandy and pebble, beaches, snow fields, stony placers). Thus, in the southern tundra of this region, the arctic spiders are represented by a large number of species that are significant components of the spider complexes. This feature sharply distinguishes them from similar complexes in the Europe and Western Siberia, which are characterized by a more "southern" appearance due to a decrease in the number of arctic species and an increase in the proportion of boreal and polyzonal ones [Tanasevitch, Koponen, 2007; Tanasevitch, Rybalov, 2010; Marusik, Koponen, 2015, etc.].

On the contrary, some hypoarctic species inhabiting a wide range of habitats in western Taimyr [Osipov, 2003], in the Ary-Mas area are limited to some azonal habitats. A similar trend (restriction only by habitats with the most smoothed conditions) was noted in the distribution of certain groups of plants in eastern Taimyr, which the authors explain by the more severe climatic conditions of this region relative to western Taimyr [Pospelova, Pospelov, 2016]. Thus, even in comparison with the latter, the spider complex of eastern Taimyr has a more pronounced arctic character. Against this background, the role of woodland is especially noticeable for the preservation of some rare species from other latitudinal fractions, as well as in the formation of relative rich hortobiontic spider assemblages under its canopy.

Acknowledgments. We dedicate this article to the memory of Yuri Mikhailovich Karbainov. As director of the Taimyr Nature Reserve, he was of great assistance in organizing research in the area. The study of terrestrial arthropods was conducted during a joint expedition with A.V. Barkalov and V.K. Zinchenko (Institute of Systematics and Ecology of Animals, Siberian Branch of the Russian Academy of Sciences, Novosibirsk), to whom we are grateful for the help in carrying out the field work. We are also grateful to Dr. A.V. Tanasevich for discussing the manuscript and valuable comments and Dr. L.B. Kholopova for editing the English. This work was supported by the Russian Founda- 
Table 4. The presence of species Araneidae, Dictynidae, Tetragnathidae in the local spider faunas of the southern tundra

Табzone. локальных фаунах пауков.

\begin{tabular}{|l|c|c|c|c|c|c|}
\hline Species & $\begin{array}{c}\text { Vorkuta, } \\
\text { Bolsheze- } \\
\text { melskaya } \\
\text { tundra }\end{array}$ & $\begin{array}{c}\text { Messo, } \\
\text { Tazovsy } \\
\text { Peninsula }\end{array}$ & $\begin{array}{c}\text { Kresty, } \\
\text { western } \\
\text { Taimyr }\end{array}$ & $\begin{array}{c}\text { Nyapan } \\
\text { range, } \\
\text { western } \\
\text { Taimyr }\end{array}$ & $\begin{array}{c}\text { Ary- } \\
\text { Mas } \\
\text { area, } \\
\text { eastern } \\
\text { Taimyr }\end{array}$ & $\begin{array}{c}\text { Ust- } \\
\text { Chaun, } \\
\text { western } \\
\text { Chukotka }\end{array}$ \\
\hline $\begin{array}{l}\text { Aculepeira carbonarioides } \\
\text { (Keyserling, 1892) }\end{array}$ & - & - & - & - & - & + \\
\hline A. packardi (Thorell, 1875) & - & - & - & - & - & + \\
\hline Aculepeira sp. & - & - & - & - & + & - \\
\hline Araneus quadratus Clerck, 1758 & - & - & - & + & - & - \\
\hline A. yukon Levi, 1971 & - & - & - & - & - & + \\
\hline Araniella displicata & - & - & - & - & + & - \\
\hline Larinioides cornutus & + & + & + & - & + & + \\
\hline Arctella lapponica Holm, 1945 & + & + & - & - & - & + \\
\hline $\begin{array}{l}\text { Dictyna alaskae Chamberlin et } \\
\text { Ivie, } 1947\end{array}$ & + & - & - & - & - & + \\
\hline D. arundinacea (Linnaeus, 1758) & - & - & + & - & - & - \\
\hline D. major & + & - & - & + & + & + \\
\hline Emblyna annulipes & - & - & - & - & + & + \\
\hline Tetragnatha extensa & + & + & + & + & + & + \\
\hline T. obtusa & - & - & - & - & + & - \\
\hline
\end{tabular}

Sources: ${ }^{1}$ Tanasevitch, Koponen [2007]; ${ }^{2}$ Marusik, Koponen [2015]; ${ }^{3}$ Eskov [1986]; ${ }^{4}$ our unpublished data; ${ }^{5}$ Marusik et al. [1992].

Использованные источники: ${ }^{1}$ Tanasevitch, Koponen [2007]; ${ }^{2}$ Marusik, Koponen [2015]; ${ }^{3}$ Еськов [1986]; ${ }^{4}$ наши неопубликованные данные; ${ }^{5}$ Marusik et al. [1992].

tion for Basic Research (project no. 14-04-01598-a) and by the Presidium of the Russian Academy of Sciences programs: "Biodiversity and Natural Resources of Russia: Structural and Functional Organization of Ecosystems and Communities" and "Evolution of the Organic World: the Role and Influence of Planetary Processes".

\section{References}

[Ary-Mas. Natural conditions, flora and vegetation of the northernmost forest massif in the world]. 1978. / Norin B.N. (ed.) Leningrad: Nauka. 190 p. [In Russian]

Chernov Yu.I., Matveyeva N.V. 2002. [Landscape-zonal distribution of the Arctic biota species] // Uspekhi sovrem. biol. Vol.122. No.1. P.26-45 [in Russian].

Gorodkov K.B. 1984. [Ranges types of insects of tundra and forest zones of European Part of U.S.S.R.] // Arealy nasekomykh Evropeiskoi chasti SSSR. Atlas. Maps. 179-221. Leningrad: Nauka. P.3-20 [in Russian].

Eskov K.Yu. 1985. [Spiders of the tundra zone of the USSR] // Ovcharenko V.I. (ed.). Fauna i ekologiya paukov SSSR. Trudy Zool. Inst. Akad. nauk SSSR. Leningrad. Vol.139. P.121-128 [in Russian].

Eskov K.Yu. 1986. [Fauna of spiders (Aranei) of the hypoarctic belt of Siberia] // Yuzhnye tundry Taimyra. Leningrad: Nauka. P.174-191 [in Russian].

Esyunin S.L. 1999. [The structure and diversity of the population of spiders of the zonal and mountain tundra of the Urals] // Zool. Zhurn. Vol.78. No.6. P.654-671 [in Russian, English summary].
Esyunin S.L. 2015. The spider (Aranei) fauna of the Urals: diversity, structure, typification // Caucasian Entomological bull. Vol.11. No.2. P.237-257.

Marusik Yu.M. 1993. [Terrestrial invertebrates] // Berman D.I. (ed.). Ekologiya basseyna reki Amguemy. Part 1. Vladivostok. P.164-185 [in Russian].

Marusik Yu.M. 2005. [Spiders and harvestmen of the coast of Taui Bay shore and adjacent parts of the northern Cisokhotia] // Biologicheskoe raznoobrazie Tauiskoi guby Okhotskogo morya. Vladivostok: Dalnauka. P.262-289 [in Russian].

Marusik Yu.M., Eskov K.Yu. 2009. Spiders (Arachnida: Aranei) of the tundra zone of Russia // Golovatch S.I., Makarova O.L., Babenko A.B., Penev L.D. (eds.). Species and communities in extreme environments. Festschrift towards 75 th anniversary and a laudatio in honour of Academician Yuri Ivanovich Chernov. Sofia-Moscow: Pensoft Publishers \& KMK Sci. Press. P.131-164.

Marusik Yu.M., Eskov K.Yu., Kim J.P. 1992. A check list of Spiders (Aranei) of Northeast Asia // Korean Arachnol. Vol.8. No.1-2. P.129-158.

Marusik Yu.M., Koponen S. 2015. New biogeographical records of spiders and harvestmen (Arachnida: Aranei \& Opiliones) from West Siberia, including an annotated list of spiders // Entomologica Fennica. Vol.26. P.165-170.

Marusik Yu.M., Koponen S., Makarova O.L. 2016. A survey of spiders (Araneae) collected on the arctic island Dolgiy $\left(69^{\circ}\right.$ 12’N), Barents Sea // Arachnology. Vol.17. No.1. P.10-24.

Marusik Yu.M., Koponen S., Vinokurov N.N. 2001. Spiders (Aranei) from northernmost forest-tundra of northeastern Yakutia $\left(70^{\circ} 35^{\prime} \mathrm{N}, 134^{\circ} 34^{\prime} \mathrm{E}\right)$ with a description of three new species // Arthropoda Selecta. Vol.10. No.4. P.351-370. 
Marusik Yu.M., Khruleva O.A. 2011. First data on spiders and harvestmen (Arachnida: Aranei \& Opiliones) from the Karaginski island, Eastern Koryakia, Kamchatka Peninsula // Arthropoda Selecta. Vol.20. No.4. P.323-329.

Marusik Yu.M., Omelko M.M., Ryabukhin A.S. 2013. New data on spiders (Aranei) from Eastern Koryakia, Kamchatka Peninsula // Arthropoda Selecta. Vol.22. No.4. P.363-377.

Mazura N.S., Esyunin S.L. 2001. Fauna and biotopic distribution of the spiders (Arachnida: Aranei) in the tundra zone of the North-East of Russian Plain // Arthropoda Selecta. Vol.10. No.1. P. 75-81.

Osipov D.V. 2003. [Structure of the spider (Aranei) fauna in southern tundra of western Taimyr] // Zool. Zhurn. Vol.82. No.10. P.1266-1270 [in Russian, English summary].

Pospelova E.B., Pospelov I.N. 2016. [Flora of the subzone of the southern tundras of the Taimyr Peninsula] // Rastitel'nyi mir Aziatskoi Rossii. Vol.1. No.21. P.80-88 [in Russian].
Tanasevitch A.V., Khruleva O.A. 2017. Spiders (Aranei) of the typical tundra subzone of the Yugorsky Peninsula, Russia // Arthropoda Selecta. Vol.26. No.4. P.341-368.

Tanasevitch A.V., Koponen S. 2007. Spiders (Aranei) of the southern tundra in the Russian Plain // Arthropoda Selecta. Vol.15 (for 2006). No.4. P.295-345.

Tanasevitch A.V., Nekhaeva A.A. 2016. Spiders (Aranei) of the Kharaulakh Mountains and the Lena River lower reaches, northern Yakutia, Russia // Arthropoda Selecta. Vol.25. No.3. P.307326.

Tanasevitch A.V., Rybalov L.B. 2010. On spiders from tundra zone of Kola Peninsula, Russia (Arachnida, Aranei) // Arthropoda Selecta. Vol.19. No.1. P.41-56.

Responsible editor K.G. Mikhailov 